\title{
PEMBUATAN DAN KARAKTERISASI STRUKTUR DAN MORFOLOGI LAPISAN ZnO:AI/GO SUBMICRON-RODS SEBAGAI MATERIAL AKTIF FOTOKATALIS
}

\author{
ANNISA NUR RAHMAWATI *, NABILAH PUTRI UTAMI, SRI SURYANINGSIH, \\ AYI BAHTIAR, ANNISA APRILIA \\ ${ }^{1}$ Departemen Fisika, FMIPA, Universitas Padjadjaran \\ Jl. Raya Bandung-Sumedang Km.21 Jatinangor 45363, Sumedang, Jawa Barat \\ *email : annisanurrahmawati8@gmail.com
}

\begin{abstract}
Abstrak. Fotokatalis merupakan reaksi perpaduan antara fotokimia dan katalis yang dapat digunakan sebagai aplikasi penjernihan air. Dalam upaya untuk meningkatkan kemampuan fotokatalitik dari senyawa $\mathrm{ZnO}$, dilakukan penambahan dopan $\mathrm{Al}$ dan senyawa GO pada proses sintesis. Tahapan pertama pembuatan lapisan $\mathrm{ZnO}, \mathrm{ZnO}: \mathrm{Al}$, $\mathrm{ZnO}: \mathrm{Al} / \mathrm{GO}$ dan $\mathrm{ZnO}: \mathrm{GO}$ dibuat melalui 2 tahapan, yaitu proses pelapisan seed layer dengan prekursor $\mathrm{Zn}\left(\mathrm{CH}_{3} \mathrm{COO}\right)_{2} 2 \mathrm{H}_{2} \mathrm{O}$ dan $\mathrm{AlCl}_{3} \quad 0,5 \%$ massa (wt $\%$ ) sebagai dopan. Tahapan kedua adalah proses penumbuhan rods dengan prekursor $\mathrm{Zn}\left(\mathrm{NO}_{3}\right)_{2} \cdot 6 \mathrm{H}_{2} \mathrm{O}$ serta $0,5 \mathrm{wt} \% \mathrm{AlCl}_{3}$ dan $0,5 \mathrm{wt} \% \mathrm{GO}$ sebagai material dopan. Berdasarkan hasil karakterisasi SEM lapisan $\mathrm{ZnO}$ :Al/GO menunjukkan adanya penurunan ukuran partikel akibat pengaruh doping Al serta pertumbuhan submicron-rods yang tidak beraturan akibat adanya perilaku self-attraction antar batang (rods). Penambahan senyawa GO (terdispersi di air) pada proses sintesis mampu meningkatkan ukuran rods dibandingkan $\mathrm{ZnO}$ murni. Hal ini kemungkinan disebabkan oleh perubahan $\mathrm{pH}$ larutan prekursor, dimana $\mathrm{pH}$ larutan GO cenderung bersifat basa. Hasil karakterisasi XRD menunjukkan bahwa seluruh sampel lapisan memiliki struktur kristal hexagonal wurtzite dengan arah kristal dominan terhadap sumbu-c. Seluruh sampel tersebut kemudian diuji fotokatalitiknya dengan menggunakan larutan uji yang mengandung senyawa Methylene blue (MB). Untuk mengetahui kinetika degradasi senyawa MB, dilakukan pengukuran spektrum absorbansi setiap rentang waktu tertentu menggunakan spektrometer UV-Vis. Berdasarkan hasil uji fotokatalis diketahui bahwa kandungan MB terdegradasi secara eksponensial sebagai fungsi waktu polynomial orde 2. Diketahui bahwa lapisan ZnO:Al/GO memiliki kemampuan mendegradasi MB sebanyak 1,9 mikrogram/mg dalam waktu uji 300 menit dibawah penyinaran lampu UV.
\end{abstract}

Kata kunci: fotokatalis, $\mathrm{ZnO}$, dip-coating, self-assembly, methylene blue

\begin{abstract}
Photocatalyst is a combination reaction between photochemical and catalyst to be used in water purification applications. To increase the photocatalytic ability of $\mathrm{ZnO}$, $\mathrm{Al}$ and $\mathrm{GO}$ were used as dopants. Preparation of $\mathrm{ZnO}, \mathrm{ZnO}: \mathrm{Al}, \mathrm{ZnO}: \mathrm{Al} / \mathrm{GO}$ and $\mathrm{ZnO}$ : GO layers were prepared in 2 steps, firstly is seed layer preparation using $\mathrm{Zn}\left(\mathrm{CH}_{3} \mathrm{COO}\right)_{2} .2 \mathrm{H}_{2} \mathrm{O}$ and $0.5(\mathrm{wt} \%)$ of $\mathrm{AlCl}_{3}$ as precursor and dopant, respectively. Secondly, is growing $\mathrm{ZnO}$ rods using $\mathrm{Zn}\left(\mathrm{NO}_{3}\right)_{2} \cdot 6 \mathrm{H}_{2} \mathrm{O}$ as a raw material, 0.5 (wt \%) $\mathrm{AlCl}_{3}$ and 0.5 (wt \%) GO as dopant materials. Based on SEM characterization, the addition of Al dopant can decrease the particle size and shows irregular growth of submicro-rods due to self-attraction behavior between rods. The addition of GO compound (dispersed in water) during synthesis process increases the rods size compared to pure $\mathrm{ZnO}$. These phenomena probably caused by changes in $\mathrm{pH}$ precursor solution became more basic, due to the $\mathrm{pH}$ value of GO solution tends to basic. The XRD characterization results for all samples shows hexagonal wurtzite crystal structure with preferred dominantly c-axis orientation. The photocatalytic activity was investigated by using Methylene blue (MB) solution. To determine the degradation kinetics of MB by involved each catalyst materials,
\end{abstract}


the absorbance spectra were measured within a certain time interval by UV-Vis Spectrometer. The MB concentration was degrading exponentially as a function of the second order polynomial. It is known that $\mathrm{ZnO}$ : $\mathrm{Al} / \mathrm{GO}$ layer has ability to degrade of 1.9 micrograms $/ \mathrm{mg} \mathrm{MB}$ in 300 minutes under irradiation by UV lamp.

Keywords: photocatalyst, ZnO, dip-coating, self-assembly, methylene blue

\section{Pendahuluan}

Pengolahan limbah merupakan teknologi yang penting untuk kehidupan manusia dan lingkungan secara global. Limbah cair merupakan permasalahan yang cukup besar, terutama limbah yang dihasilkan dari industri tekstil [1]. Air yang tercemar, memiliki karakteristik khusus yang dapat dibedakan dari air bersih, baik secara fisik, kimia maupun biologi yang dapat ditunjukkan dengan berbagai indikator/tanda bahwa air dalam keadaan tercemar [2]. Untuk mengatasi pencemaran air tersebut, terdapat beberapa metode yang dilakukan untuk menjernihkan air [3], diantaranya adalah dengan menggunakan material fotokatalis di bawah iradiasi sinar matahari. Tantangan terbesar dari metode ini adalah mendapatkan material fotokatalis yang dapat bekerja dibawah rentang spektrum radiasi matahari yang lebih luas [4]. Fotokatalis melibatkan reaksi antara fotokimia dan katalis. Dimana proses reaksi fotokimia melibatkan suatu cahaya (foton), serta katalis yang mampu mempercepat fotoreaksi melalui interaksinya [5].

Senyawa metal oksida $\mathrm{ZnO}$ sering digunakan sebagai material fotokatalis karena memiliki fotosensitivitas yang tinggi, karakteristik mekanik yang baik, biaya produksi yang cukup rendah, dan aman bagi lingkungan [6]. Peran $\mathrm{ZnO}$ sebagai fotokatalis bergantung pada beberapa faktor antara lain ukuran partikel, bentuk/morfologi, dan konsentrasi larutan pada saat uji fotokatalis. Beberapa penelitian menunjukkan bahwa pengembangan semikonduktor pada suatu adsorben dapat meningkatkan aktivitas fotokatalitik dalam proses degradasi senyawa organik maupun logam berat [7]. Semikonduktor $\mathrm{ZnO}$ memiliki keuntungan yang mampu menyerap spektrum matahari dan kuantum cahaya lebih banyak dibandingkan dengan $\mathrm{TiO}_{2}$ [8]. Material $\mathrm{ZnO}$ memiliki jarak celah pita yang lebih besar $(3,37 \mathrm{eV})$ daripada $\mathrm{TiO}_{2}$ sebesar 3,2 eV [9], sehingga hanya bisa diaplikasikan dibawah sinar UV $(\lambda<387 \mathrm{~nm})$. Logam Al umum digunakan sebagai metal dopant pada $\mathrm{ZnO}$, karena menghasilkan lapisan dengan transparansi dan konduktivitas yang tinggi [10]. Selain itu, pemberian doping Al juga diketahui dapat mereduksi ukuran partikel ZnO sehingga dapat meningkatkan aktifitas luas permukaan menjadi lebih besar. Berdasarkan penelitian sebelumnya, penambahan dopan $\mathrm{Al}$ pada $\mathrm{ZnO}$ paling efektif dalam meningkatkan sifat listrik dan optik [4].

Graphene merupakan material karbon 2D yang memiliki tebal satu atom karbon [11] dengan luas permukaan spesifik $2630 \mathrm{~m}^{2} \mathrm{~g}^{-1}$ [12] serta memiliki sifat mekanik, termal, listrik dan optik yang baik [13]. Senyawa karbon dalam bentuk Grafit yang kemudian diubah menjadi oksida grafit merupakan prekursor graphene oxide (GO) [14]. Keuntungan utama dari GO adalah harganya yang murah dengan raw material yang melimpah dan tersedia di alam. GO merupakan material yang banyak digunakan berkaitan dengan karakteristik unik dari material graphene, namun memiliki sifat yang kurang baik seperti luas permukaan spesifik yang rendah, memiliki kerapatan gugus oksigen yang tinggi, dan bersifat isolator [15]. Xu dkk menjelaskan bahwa graphene-hybridized $\mathrm{ZnO}$ fotokatalis menunjukkan peningkatan aktivitas fotokatalitik untuk degradasi pewarna organik, sebesar 4 kali dari $\mathrm{ZnO}$ biasa. Penambahan $\mathrm{Al}$ dan senyawa GO diharapkan dapat meningkatkan 
kemampuan degradasi senyawa polutan Methylene blue (MB) dan mampu mereduksi ukuran pertikel $\mathrm{ZnO}$ sehingga luas permukaan spesifik dapat ditingkatkan. Penambahan senyawa GO diharapkan dapat meningkatkan proses degradasi polutan karena GO merupakan material adsorban dan mampu mereduksi proses rekombinasi muatan sehingga proses fotokatalisnya terjadi secara lebih cepat.

Oleh karena itu, pada penelitian ini dikaji karakteristik fotokatalis lapisan tipis $\mathrm{ZnO}$ yang didoping oleh atom $\mathrm{Al}$ dan GO. Karakteristik fotokatalis tersebut kemudian dikaitkan dengan struktur dan morfologi lapisan $\mathrm{ZnO}$ :Al/GO yang dihasilkan. Pada penelitian ini fotokatalis $\mathrm{ZnO}, \mathrm{ZnO}: \mathrm{Al}, \mathrm{ZnO}: \mathrm{Al} / \mathrm{GO}$ dan $\mathrm{ZnO}: \mathrm{GO}$ dibuat dalam bentuk lapisan menggunakan metode sol-gel dengan teknik dip-coating untuk pelapisan seed layer dan self assembly untuk penumbuhan $\mathrm{ZnO}$ rod. Senyawa $\mathrm{ZnO}: \mathrm{Al} / \mathrm{GO}$ hasil sintesis kemudian dikarakterisasi struktur dan morfologinya menggunakan, XRD dan SEM-EDS. Sedangkan pengujian sifat fotokatalitik dilakukan dengan menggunakan larutan metil biru dan diamati perubahan kandungan MB menggunakan Spektrofotometer UV-Vis.

\section{Metode Penelitian}

\subsection{Pembuatan Lapisan ZnO, ZnO:Al, ZnO:Al/GO dan ZnO:GO}

Pembuatan lapisan $\mathrm{ZnO}, \mathrm{ZnO}: \mathrm{Al}, \mathrm{ZnO}: \mathrm{Al} / \mathrm{GO}$ dan $\mathrm{ZnO}$ :GO dilakukan melalui beberapa tahapan. Tahapan pertama adalah preparasi lapisan tipis $\mathrm{ZnO}: \mathrm{Al}$ seed layer menggunakan metode sol-gel dengan teknik pelapisan dip-coating. Bahan yang digunakan adalah Zinc acetate dihydrate $\left(\mathrm{Zn}\left(\mathrm{CH}_{3} \mathrm{COO}\right)_{2} 2 \mathrm{H}_{2} \mathrm{O}\right.$ sebagai prekursor, Methoxyethanol sebagai pelarut dalam pembuatan $\mathrm{ZnO}$ seed layer, Alumunium chloride $\left(\mathrm{AlCl}_{3}\right)$ sebagai dopan dan Diethanolamine (DEA) sebagai stabilizer/ligan.

Tahapan kedua adalah sintesis $\mathrm{ZnO}, \mathrm{ZnO}: \mathrm{Al}, \mathrm{ZnO}: \mathrm{Al} / \mathrm{GO}$ dan $\mathrm{ZnO}: \mathrm{GO}$ menggunakan metode self assembly untuk penumbuhan struktur submicron-rods. Bahan yang digunakan adalah Zinc nitrate hexahydrate $\mathrm{Zn}\left(\mathrm{NO}_{3}\right)_{2} \cdot 6 \mathrm{H}_{2} \mathrm{O}$ (Aldrich, 98\%), deionized (DI) water, Alumunium chloride $\mathrm{AlCl}_{3}$, Graphene oxide (GO) dan hexamethylenetetramine (HMTA, Aldrich, 99\%). Kemudian lapisan $\mathrm{ZnO}, \mathrm{ZnO}: \mathrm{Al}$, $\mathrm{ZnO}: \mathrm{Al} / \mathrm{GO}$ dan ZnO:GO dikarakterisasi XRD, SEM dan EDS agar diketahui struktur kristal, morfologi lapisan dan komposisi dari setiap unsur yang terdapat pada lapisan $\mathrm{ZnO}, \mathrm{ZnO}: \mathrm{Al}, \mathrm{ZnO}: \mathrm{Al} / \mathrm{GO}$ dan $\mathrm{ZnO}$ :GO submicron-rods tersebut.

\subsection{Pengujian Fotokatalitik}

Tahap pengujian fotokatalis dilakukan dengan menggunakan larutan Methylene blue sebagai larutan uji. Methylene blue dilarutkan dengan menggunakan DI Water sehingga didapat larutan sebanyak $0,33 \mu \mathrm{M}$ atau setara dengan 1,07 ppm. Larutan uji kedua adalah dengan konsentrasi $10^{-6} \mathrm{~mol} / \mathrm{L}(0,033 \mu \mathrm{M})$. Kemudian larutan diambil sebanyak $42 \mathrm{ml}$ dan dituangkan pada petridis kaca, lalu lapisan $\mathrm{ZnO}$, $\mathrm{ZnO}: \mathrm{Al}, \mathrm{ZnO}: \mathrm{Al} / \mathrm{GO}$ dan $\mathrm{ZnO}: \mathrm{GO}$ submicron-rods disimpan dalam petridis kaca tersebut dengan posisi lapisan menghadap keatas. Setelah itu lapisan $\mathrm{ZnO}, \mathrm{ZnO}: \mathrm{Al}$, $\mathrm{ZnO}: \mathrm{Al} / \mathrm{GO}$ dan $\mathrm{ZnO}: \mathrm{GO}$ disinari oleh lampu UV, sampai kandungan Methylene blue terurai yang ditandai dengan larutan yang semakin jernih. Untuk mengamati laju degradasinya sampel diambil pada menit ke 60, 180 dan dihentikan sampai dengan penyinaran 300 menit. Selanjutnya diamati spektrum absorbansi larutan uji menggunakan Spectroscopy UV-Vis. 


\section{Hasil dan Pembahasan}

Setelah lapisan selesai dibuat, sampel kemudian ditimbang agar diketahui massanya. Penimbangan tersebut dilakukan untuk menentukan konsentrasi Methylene Blue yang digunakan saat uji fotokatalis. Berikut massa submicron-rods yang diperoleh.

Tabel 1. Massa hasil lapisan $\mathrm{ZnO}, \mathrm{ZnO}: \mathrm{Al}, \mathrm{ZnO}: \mathrm{Al}: \mathrm{GO}$ dan $\mathrm{ZnO}: \mathrm{GO}$

\begin{tabular}{cc}
\hline Sampel & Massa Sampel (mg) \\
\hline $\mathrm{ZnO}$ & 1,57 \\
$\mathrm{ZnO}: \mathrm{Al}$ & 2,75 \\
$\mathrm{ZnO}: \mathrm{Al} / \mathrm{GO}$ & 12,8 \\
$\mathrm{ZnO}: \mathrm{GO}$ & 16,7 \\
\hline
\end{tabular}

Tabel 1 diatas diperoleh dari hasil submicron-rods dengan bentuk heksagonal sempurna. Dari hasil tersebut terlihat bahwa ukuran rods dari $\mathrm{ZnO}$ dengan doping Al lebih kecil dibandingkan dengan $\mathrm{ZnO}: \mathrm{Al} / \mathrm{GO}$ dan $\mathrm{ZnO}$ :GO. Hasil karakteriasi SEM ditunjukkan pada Gambar 1.

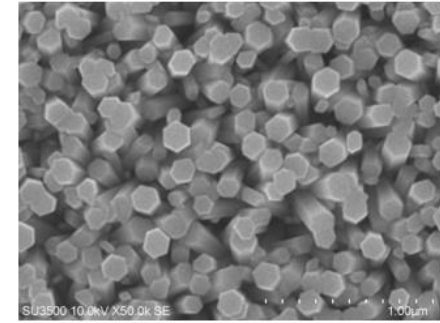

(a)

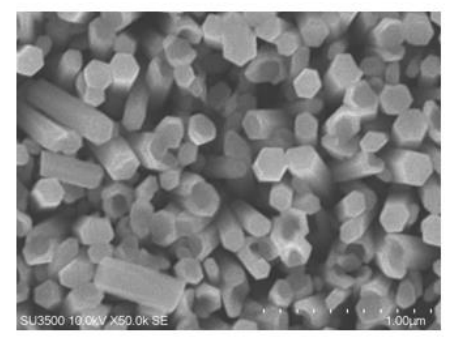

(c)

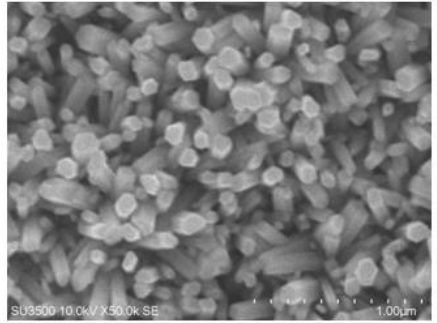

(b)

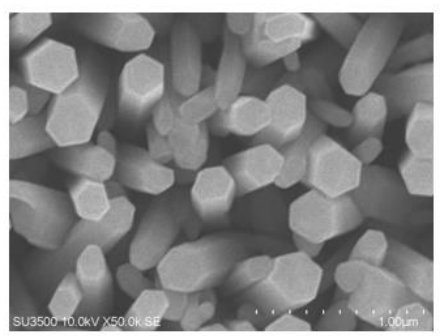

(d)

Gambar 1. Hasil karakterisasi SEM lapisan (a)ZnO (b) $\mathrm{ZnO}: \mathrm{Al}$ (c) $\mathrm{ZnO}: \mathrm{Al} / \mathrm{GO}$ dan (d) $\mathrm{ZnO}: \mathrm{GO}$

Pada Gambar 1 menunjukkan morfologi dari (a) $\mathrm{ZnO}$, (b) $\mathrm{ZnO}: \mathrm{Al}$, (c) $\mathrm{ZnO}: \mathrm{Al} / \mathrm{GO}$ dan (d) ZnO:GO dengan waktu penumbuhan 180 menit. Dari hasil karakterisasi tersebut dapat terlihat bahwa lapisan $\mathrm{ZnO}$ memiliki bentuk yang seragam dengan diameter rata-rata rods sebesar $148 \mathrm{~nm}$.

Sampel yang didoping dengan Al menunjukkan ukuran yang lebih kecil dan rapat dibandingkan dengan sampel $\mathrm{ZnO}, \mathrm{ZnO}: \mathrm{Al} / \mathrm{GO}$ dan $\mathrm{ZnO}$ :GO. Bila dibandingkan dengan hasil pengukuran XRD pada diameter $\mathrm{ZnO}$, pengaruh adanya $\mathrm{Al}$ pada lapisan $\mathrm{ZnO}$ :Al mampu memperkecil ukuran kristal $\mathrm{ZnO}$ submicron-rods, hal ini disebabkan karena atom Al memiliki diameter atomik yang lebih kecil apabila 
dibandingkan dengan atom $\mathrm{Zn}$, sehingga ketika atom $\mathrm{Al}$ menempati posisi atom $\mathrm{Zn}$ akan mereduksi ukuran kristal/partikel $\mathrm{ZnO}$. Keberadaan atom $\mathrm{Al}$ juga mempengaruhi pertumbuhan rods, disebabkan karena adanya perilaku selfattraction yang menyebabkan pertumbuhan submicron-rods menjadi tidak beraturan dengan penjajaran rods yang cenderung lebih rapat [10].

Lapisan $\mathrm{ZnO}: \mathrm{Al} / \mathrm{GO}$ menunjukkan bentuk ukuran rods yang lebih besar dan tinggi dibandingkan dengan sampel lapisan $\mathrm{ZnO}$ :Al dengan aspek rasio (L/d) sebesar 13.07 (Tabel 1). Pada hasil SEM ZnO:Al/GO juga terlihat bahwa pertumbuhan rods tidak beraturan akibat adanya pengaruh doping $\mathrm{Al}$ yang menyebabkan adanya perilaku self-attraction. Pada sampel ini juga terjadi peningkatan diameter dan tinggi submicro-rods apabila dibandingkan dengan doping $\mathrm{ZnO}$ :Al saja. Lapisan $\mathrm{ZnO}$ yang didoping dengan $\mathrm{GO}$ menunjukkan bentuk yang tidak seragam dan ukuran rods sampel yang lebih besar. Akibat besarnya diameter lapisan dan tinggi rods tersebut, hasil uji fotokatalisnya menunjukan penurunan nilai absorbansi yang lebih cepat dibandingkan dengan sampel lainnya. Ukuran diameter, tinggi dan aspek rasio yaitu perbandingan antara tinggi dengan diameter (L/d) dari lapisan $\mathrm{ZnO}, \mathrm{ZnO}: \mathrm{Al}, \mathrm{ZnO}: \mathrm{Al} / \mathrm{GO}$ dan $\mathrm{ZnO}$ :GO submicron-rods dapat terlihat pada tabel 1. Pada Gambar 2 diperlihatkan hasil SEM untuk cross-section dari lapisan (a) ZnO, (b) $\mathrm{ZnO}: \mathrm{Al}$, (c) $\mathrm{ZnO}: \mathrm{Al} / \mathrm{GO}$ dan (d) $\mathrm{ZnO}: \mathrm{GO}$.

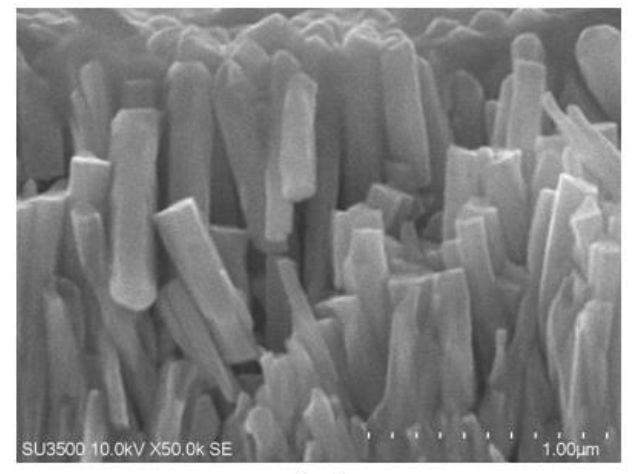

(c)

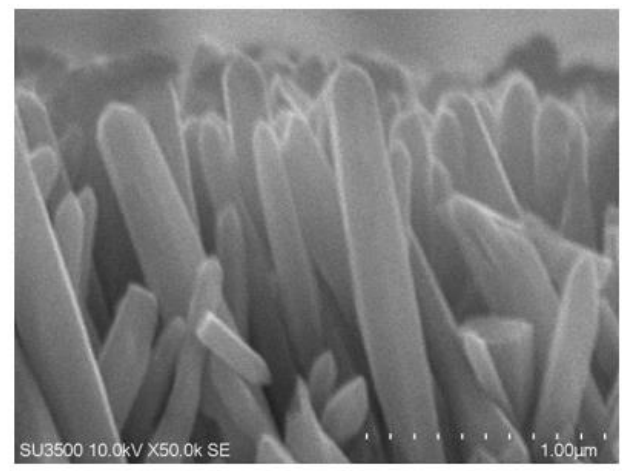

(d)

Gambar 2. Hasil SEM cross-section (a) $\mathrm{ZnO}$, (b) $\mathrm{ZnO}: \mathrm{Al}$, (c) $\mathrm{ZnO}: \mathrm{Al} / \mathrm{GO}$ dan (b) $\mathrm{ZnO}: \mathrm{GO}$

Pada lapisan ZnO:Al/GO, submicron-rods memiliki penjajaran yang tidak beraturan, sedangkan untuk lapisan $\mathrm{ZnO}$ :GO, submicron-rods yang terbentuk berukuran besar dengan tinggi lebih besar dibandingkan sampel lainnya dengan penjajaran yang cenderung lebih teratur. Ukuran rods yang lebih besar pada sampel dengan doping GO dipengaruhi akibat $\mathrm{pH}$ larutan penumbuhnya, dimana GO terdispersi stabil pada larutan degan $\mathrm{pH}$ 7-11 atau berada pada $\mathrm{pH}$ basa [16]. Penambahan senyawa GO yang memiliki $\mathrm{pH}$ basa meningkatkan jumlah $\mathrm{OH}$ pada larutan penumbuh. Meningkatnya jumlah $\mathrm{OH}$ tersebut menyebabkan pembentukan partikel $\mathrm{ZnO}$ menjadi lebih banyak dan cepat sehingga berefek pada ukuran (dimensi) dan massa $\mathrm{ZnO}$ yang dihasilkan.

Karakterisasi EDS digunakan untuk mengetahui kandungan unsur pada lapisan $\mathrm{ZnO}: \mathrm{Al} / \mathrm{GO}$ dan $\mathrm{ZnO}: \mathrm{GO}$. Berdasarkan hasil EDS yang diperlihatkan pada tabel 2 terlihat bahwa masing-masing sampel mengandung komposisi unsur $\mathrm{Zn}, \mathrm{O}, \mathrm{Al}$ dan 
C. Atom $\mathrm{Zn}$ dan $\mathrm{O}$ berasal dari molekul $\mathrm{ZnO}$ yang terbentuk dari hasil sintesis sedangkan atom $\mathrm{C}$ berasal dari Graphene oxide. Unsur $\mathrm{Zn}$ pada sampel $\mathrm{ZnO}: \mathrm{Al} / \mathrm{GO}$ memiliki persen berat relatif sebesar 51,29\%, unsur O sebesar 48,7\%, unsur Al 0\% dan unsur $\mathrm{C} 0 \%$. Pada sampel $\mathrm{ZnO}$ :GO unsur $\mathrm{Zn}$ memiliki persentase berat relatif sebesar $52,43 \%$, unsur O $47,56 \%$ dan unsur C $0,01 \%$. Perbandingan antara atom Zn dan O pada setiap sampel ditunjukkan pada Tabel 2.

Tabel 2. Hasil Karakterisasi EDS

\begin{tabular}{ccccc}
\hline & Elemen & \% Massa & \% Atom & $\mathrm{Zn}: \mathrm{O}: \mathrm{C}: \mathrm{Al}$ \\
\hline & $\mathrm{C}$ & 0 & 0 & \\
ZnO:Al/GO & $\mathrm{O}$ & 18,86 & 48,7 & $1: 0,95: 0: 0$ \\
& $\mathrm{Zn}$ & 81,14 & 51,29 & \\
& $\mathrm{Al}$ & 0 & 0 & $\mathrm{Zn}: \mathrm{O}: \mathrm{C}$ \\
\hline & Elemen & \% Massa & \% Atom & $1: 0,90: 0$ \\
ZnO:GO & $\mathrm{C}$ & 0 & 0,01 & \\
& $\mathrm{O}$ & 18,16 & 47,56 & 52,43 \\
\hline
\end{tabular}

Dalam perbandingan secara stoikiometri, nilai rasio atom $\mathrm{Zn}: \mathrm{O}$ seharusnya adalah 1:1. Perbedaan nilai rasio perbandingan dengan rasio stoikiometri ini dapat disebabkan karena terdapat defect yang terjadi selama proses sintesis berlangsung. Nilai rasio atomic yang paling mendekati adalah pada sampel dengan pemberian dopan $\mathrm{Al}$. Pada sampel $\mathrm{ZnO}: \mathrm{Al} / \mathrm{GO}$, atomik\% dari unsur $\mathrm{Al}$ dan $\mathrm{C}$ tidak terdeteksi. $\mathrm{Hal}$ ini disebabkan karena rendahnya konsentrasi $\mathrm{Al}$ dan $\mathrm{C}$ yang diberikan. Begitu pula pada sampel $\mathrm{ZnO}: \mathrm{GO}$, dimana atomic\% unsur $\mathrm{C}$ hanya terdeteksi sekitar $0,01 \%$. Hal tersebut disebabkan karena batas deteksi EDS adalah sebesar 0,1 (wt\%), sehingga EDS tidak dapat mendeteksi material dengan konsentrasi dibawah 0,01 $(\mathrm{wt} \%)$ [18].

Karakterisasi XRD digunakan untuk mengetahui struktur kristal lapisan dengan melihat puncak difraksi dan indeks miller dari sampel. Karakterisasi ini dilakukan dengan menggunakan sumber $\mathrm{Cu}$ dengan panjang gelombang $\lambda=1,54060 \AA$ dengan interval $2 \theta$ pada $5^{\circ}-70^{\circ}$. Hasil dari karakterisasi ini diperoleh spektrum XRD yang menyatakan hubungan antara $2 \theta$ dengan intensitas difraksi. Untuk menentukan kesesuaian struktur ksrital yang terbentuk, dilakukan pencocokan data $2 \Theta$ difraktogram hasil analisis dengan data dari JCPDS (Joint Committee Powder Diffraction Sandar). Pola difraksi standar yang digunakan sebagai pembanding adalah JCPDS No. 36-1451.Karakterisasi XRD dilakukan pada sampel lapisan ZnO, $\mathrm{ZnO}: \mathrm{Al}, \mathrm{ZnO}: \mathrm{Al} / \mathrm{GO}$ dan $\mathrm{ZnO}$ :GO submicron-rods submicron-rods. Pola XRD dari lapisan $\mathrm{ZnO}, \mathrm{ZnO}: \mathrm{Al}, \mathrm{ZnO}: \mathrm{Al} / \mathrm{GO}$ dan $\mathrm{ZnO}$ submicron-rods ditunjukkan pada Gambar 3. 


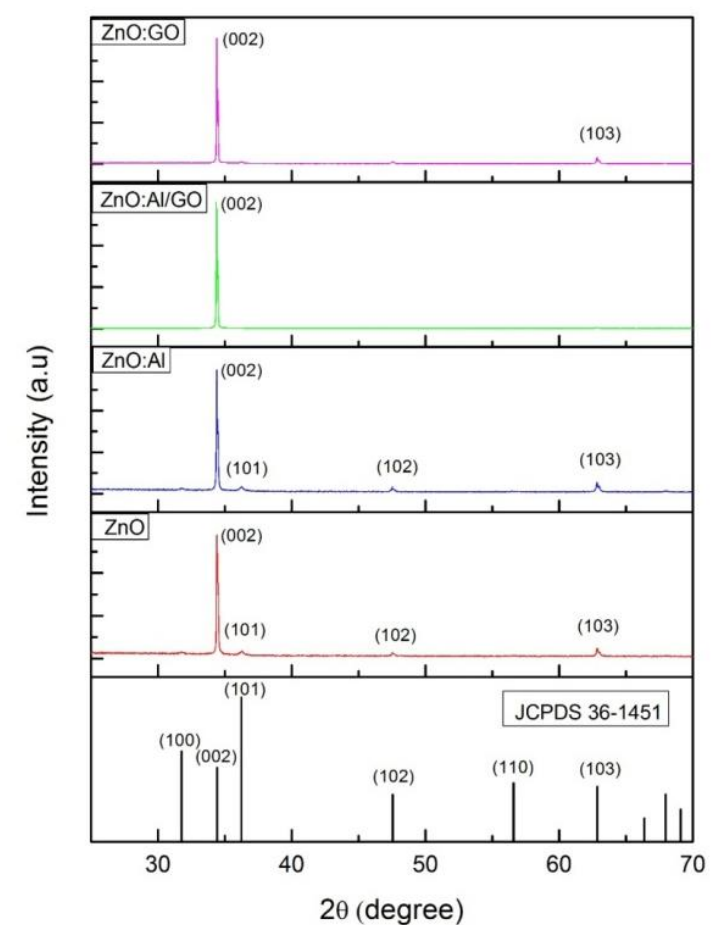

Gambar 3. Hasil karakterisasi XRD sampel $\mathrm{ZnO}, \mathrm{ZnO}: \mathrm{Al}, \mathrm{ZnO}: \mathrm{Al} / \mathrm{GO}$ dan $\mathrm{ZnO}: \mathrm{GO}$

Dari grafik hasil XRD yang diperoleh, dari keempat sampel menunjukkan pola difraksi yang sama, dimana puncak dengan intensitas tertinggi berada pada bidang hkl (002). Berikut perbandingan data bidang hkl Wurtzite dan data $2 \Theta$ dari JCPDS No. 36-1451 dan data yang diperoleh, dapat terlihat pada Tabel 3 dibawah ini.

Tabel 3. Data perbandingan hkl dan 2Ө Wurtzite JCPDS No. 36-1451 dan hasil percobaan

\begin{tabular}{cccccccccc}
\hline \multicolumn{2}{c}{ JCPDS No 36- } & \multicolumn{2}{c}{ ZnO } & \multicolumn{2}{c}{ ZnO:Al } & \multicolumn{2}{c}{ ZnO:Al/GO } & \multicolumn{2}{c}{ ZnO:GO } \\
\hline $\mathbf{( 1 0 0 )}$ & $31,769^{\circ}$ & $(100)$ & - & $(100)$ & $31,808^{\circ}$ & $(100)$ & - & $(100)$ & - \\
$(\mathbf{0 0 2})$ & $34,421^{\circ}$ & $(002)$ & $34,429^{\circ}$ & $(002)$ & $34,409^{\circ}$ & $(002)$ & $34,388^{\circ}$ & $(002)$ & $34,409^{\circ}$ \\
$(\mathbf{1 0 1})$ & $36,252^{\circ}$ & $(101)$ & $36,293^{\circ}$ & $(101)$ & $36,272^{\circ}$ & $(101)$ & - & $(101)$ & - \\
$(\mathbf{1 0 2})$ & $47,538^{\circ}$ & $(102)$ & $47,577^{\circ}$ & $(102)$ & $47,516^{\circ}$ & $(102)$ & - & $(102)$ & - \\
$(\mathbf{1 0 3})$ & $62,862^{\circ}$ & $(103)$ & $62,855^{\circ}$ & $(103)$ & $62,834^{\circ}$ & $(103)$ & - & $(103)$ & $62,83^{\circ}$ \\
\hline
\end{tabular}

Dari hasil pola XRD pada Gambar 3. terlihat bahwa intensitas puncak difraksi sangat tajam terdapat pada bidang hkl (002). Hal ini menunjukkan bahwa semua lapisan yang terbentuk dominan mengarah pada sumbu-c. Keberadaan puncak (100), (101), (102) dan (103) juga menunjukkan bahwa sampel tersebut memiliki struktur hexagonal wurtzite. $\mathrm{ZnO}$ dengan struktur hexagonal wurtzite memiliki ukuran yang dipengaruhi oleh kisi a dan c. Untuk mengetahui ukuran kristal, dapat digunakan persamaan Debye Scherrer. Dimana penentuan ukuran ini merujuk pada puncak-puncak utama dari pola difraktogram. Persamaan Debye Scherrer dirumuskan dengan:

$$
D=\frac{k \lambda}{\beta \cos \theta_{\beta}}
$$


Dalam hal ini, D merupakan ukuran (diameter) kristal, $\lambda$ adalah panjang gelombang sinar-X yang digunakan, $\theta_{\beta}$ adalah sudut Bragg, $\beta$ adalah FWHM (Full Width Half Minimum) atau salah satu puncak yang dipilih dan $k$ adalah konstanta material yang nilainya kurang dari $1(\mathrm{k} \approx 0,9)$. Hasil perhitungan kemudian ditampilkan pada Tabel 4. Parameter kisi kristal $\mathrm{c}$ dan a dari sturktur kristal wurtzite $\mathrm{ZnO}$ dapat dihitung dengan menggunakan persamaan dibawah ini:

$$
\begin{aligned}
& c=\frac{\lambda}{\sin \theta} \\
& a=\sqrt{\frac{1}{3}} \frac{\lambda}{\sin \theta}
\end{aligned}
$$

Tabel 4. Efisiensi masing-masing sampel

\begin{tabular}{cccccc}
\hline $\begin{array}{c}\text { Efisiensi } \\
\text { degradasi/waktu }\end{array}$ & ZnO & ZnO:Al & ZnO:Al/GO & ZnO:GO & UV \\
\hline $\mathbf{0}$ & $0 \%$ & $0 \%$ & $0 \%$ & $0 \%$ & $0 \%$ \\
$\mathbf{6 0}$ & $76 \%$ & $26 \%$ & $38 \%$ & $49 \%$ & $26 \%$ \\
$\mathbf{1 8 0}$ & $90 \%$ & $52 \%$ & $75 \%$ & $86 \%$ & $28 \%$ \\
$\mathbf{3 0 0}$ & $90 \%$ & $63 \%$ & $88 \%$ & $95 \%$ & $32 \%$ \\
\hline
\end{tabular}

Ukuran kristal ZnO pada orientasi bidang hkl (002) adalah sebesar 90,18 nm. Dengan adanya penambahan dopan Al mampu mereduksi ukuran kristal menjadi $80,94 \mathrm{~nm}$. Penurunan intensitas difraksi pada sampel dengan penambahan Al sebagai dopan berkaitan pula dengan penurunan ukuran kristal. Atom Al memiliki diameter atomik yang lebih kecil apabila dibandingkan dengan atom $\mathrm{Zn}$, sehingga atom $\mathrm{Al}$ menempati posisi atom $\mathrm{Zn}$ [10]. Diameter ion $\mathrm{Al}^{+3}(0,039 \mathrm{~nm})$ memiliki nilai yang lebih kecil daripada $\mathrm{Zn}^{2+}(0,06 \mathrm{~nm})$, sehingga ketika atom $\mathrm{Al}$ menempati lokasi $\mathrm{Zn}$ dalam sebuah kisi kristal maka ukuran kristal tersebut akan tereduksi [17].

Pada sampel $\mathrm{ZnO}: \mathrm{Al} / \mathrm{GO}$ dan $\mathrm{ZnO}: \mathrm{GO}$ juga terjadi penurunan puncak $2 \theta$ dibandingkan dengan $\mathrm{ZnO}$ murni dan terlihat pula adanya kenaikan diameter kristal pada kedua sampel tersebut. Tidak teramatinya puncak difraksi GO disebabkan karena rendahnya konsentrasi GO yang diberikan serta kemungkinan tereduksinya senyawa GO menjadi rGO. Hasil XRD tersebut juga menunjukkan bahwa tidak terdapat impurity yang terdeteksi pada keempat sampel tersebut. Untuk mengetahui keberadaan dopan (Al dan GO) pada lapisan yang dihasilkan perlu dikarakterisasi lebih lajut, salah satunya adalah dengan karakterisasi spektrum Raman. Jika ternyata keberadaan $\mathrm{Al}$ dan $\mathrm{GO}$ tetap tidak terdeteksi, maka penambahan senyawa dopan $\mathrm{AlCl}_{3}$ dan larutan $\mathrm{GO}$ hanya memengaruhi proses penumbuhan $\mathrm{ZnO}$ rods yang berkaitan dengan perubahan kondisi $\mathrm{pH}$ larutan penumbuh.

Pengujian fotokatalitik dilakukan dengan menggunakan larutan uji Methylene blue dengan konsentrasi sebesar $10^{-5} \mathrm{~mol} / \mathrm{L}(0,335 \mathrm{ppm})$. $\mathrm{ZnO}: \mathrm{Al} / \mathrm{GO}$ dan $\mathrm{ZnO}$ :GO submicro-rods direndam dalam larutan MB $10 \mathrm{~mL}$ kemudian ditambahkan Aquades sebanyak 30mL. Sampel $\mathrm{ZnO}$ dan $\mathrm{ZnO}$ :Al direndam dalam larutan $\mathrm{MB}$ yang konsentrasinya telah diencerkan sebanyak 10x dari larutan yang telah dibuat. Untuk sampel $\mathrm{ZnO}$ dan $\mathrm{ZnO}: \mathrm{Al}$, konsentrasi larutan uji yang digunakan berbeda dengan 
larutan sebelumnya, hal ini disebabkan karena katalis yang diperoleh dari hasil sintesis memiliki massa yang lebih kecil.

Selanjutnya lapisan yang sudah terendam larutan MB disinari dibawah lampu UV. Berdasarkan pengamatan, MB dapat terdegradasi selama 300 menit. Pengambilan sampel dilakukan pada rentang waktu 60 menit, 180 menit, 300 menit. Kemudian larutan MB tersebut di karakterisasi dengan Spectroscopy Uv-Vis untuk melihat kandungan MB yang tersisa. Dalam penelitian ini, proses peluruhan atau degradasi dari MB lebih fit ketika menggunakan eksponensial berpangkat polynomial orde 2 dengan persamaan 4 .

$$
-\ln \left[\frac{A}{A_{0}}\right]=k t
$$

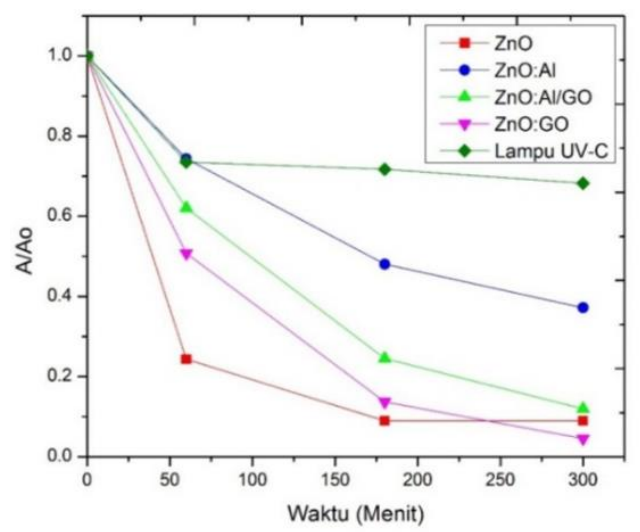

(a)

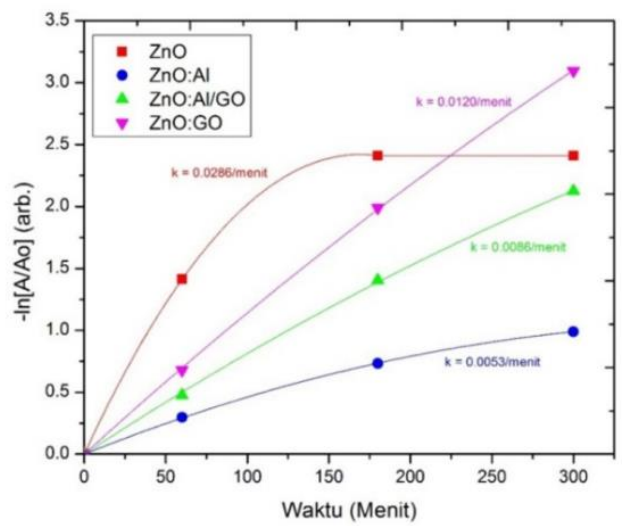

(b)

Gambar 4. (a) grafik penurunan konsentrasi MB dibawah penyinaran lampu UV dan (b) grafik konstanta degradasi MB dibawah penyinaran lampu UV

Dari grafik konstanta laju degradasi fotokatalitik yang diperlihatkan oleh Gambar 4, diperoleh nilai $\mathrm{k}$ pada sampel $\mathrm{ZnO}$ adalah 0,0286/menit, $\mathrm{ZnO}: \mathrm{Al}$ 0,0053/menit, ZnO:Al/GO 0,0086/menit dan ZnO:GO 0,0120/menit. Pada waktu 60 menit pertama, laju degradasi MB belum terlihat signifikan, hal ini disebabkan karena sampel $\mathrm{ZnO}, \mathrm{ZnO}: \mathrm{Al}, \mathrm{ZnO}: \mathrm{Al} / \mathrm{GO}$ dan $\mathrm{ZnO}$ GO membutuhkan waktu untuk mencapai titik kesetimbangan untuk mendegradasi MB. Namun dibandingkan sampel lainnya sampel ZnO lebih cepat mendegradasi MB pada 60 menit pertama tersebut. Dari percobaan dapat terlihat bahwa laju degradasi pada sampel $\mathrm{ZnO}: \mathrm{Al}$ memiliki waktu degradasi yang lebih lama dibandingkan sampel yang lain dengan nilai konstanta laju degradasi yang kecil. Hal ini disebabkan karena rods yang terbentuk pada seed layer terlalu rapat sehingga proses degradasi fotokatalisnya lebih lama. Pada penelitian ini, dihitung juga nilai efisiensi degradasi untuk masingmasing sampel pada waktu 300 menit, yang ditunjukkan pada Tabel 4 dibawah ini.

Sampel ZnO:Al yang juga didoping dengan GO menunjukan peningkatan aktivitas fotokatalitik sehingga laju degradasinya meningkat dibandingkan sampel $\mathrm{ZnO}$ :Al. Selain itu, sampel $\mathrm{ZnO}$ submicron-rods yang didoping dengan GO menunjukkan proses degradasi lebih cepat dibandingkan dengan sampel $\mathrm{ZnO}: \mathrm{Al} / \mathrm{GO}$. 
Berdasarkan hasil SEM, penambahan dopan GO terhadap ZnO menyebabkan struktur submicron-rods yang tidak beraturan dan terjadi peningkatan diameter rods, sehingg mampu meningkatkan aktivitas fotokatalis karena luas permukaan aktifnya meningkat.

Berdasarkan efisiensi dari masing-masing sampel dapat terlihat bahwa sampel $\mathrm{ZnO}$ :GO memiliki nilai efisiensi tertinggi yaitu 95\%, kemudian sampel $\mathrm{ZnO}$ dengan efisiensi 90\%, kemudian sampel $\mathrm{ZnO}$ :Al/GO yaitu $88 \%$ dan terakhir, sampel $\mathrm{ZnO}$ :Al yang memiliki nilai efisiensi terendah dengan nilai $63 \%$. Kemudian dihitung juga efisiensi degradasi MB dengan lampu UV tanpa menggunakan katalis yaitu diperoleh efisiensi sebesar 32\%. Hal tersebut menyatakan bahwa lampu UV juga berperan dalam pendegradasian konsentrasi MB dan dengan penambahan katalis terbukti mampu menambah efisiensi fotokatalitik.

Perbandingan antara nilai efisiensi degradasi tidak dapat dibandingkan karena berkaitan dengan perbandingan antara MB dengan serbuk material katalis yang berbeda, apabila ingin dibandingkan, maka nilainya harus seragam. Perbandingan MB dengan serbuk material katalis untuk sampel $\mathrm{ZnO}$ adalah 0,003, untuk sampel $\mathrm{ZnO}: \mathrm{Al}$ adalah 0,002, untuk sampel $\mathrm{ZnO}: \mathrm{Al} / \mathrm{GO}$ adalah 0,004 dan sampel $\mathrm{ZnO}: \mathrm{GO}$ adalah 0,003. Dari perbandingan tersebut dapat diketahui bahwa perbandingan terbesar adalah pada sampel $\mathrm{ZnO}: \mathrm{Al} / \mathrm{GO}$. Nilai ini kemudian digunakan untuk menghitung massa MB yang mampu tereduksi oleh $1 \mathrm{mg}$ katalis pada waktu 300 menit. Nilai tersebut kemudian dikurangi dengan nilai yang dihasilkan oleh UV agar diperoleh hasil akhir nilai massa MB yang menunjukkan kemampuan material dalam mereduksi MB pada waktu 300 menit.

Koefisien laju degradasi berkaitan dengan kecepatan reaksi/aktivitas fotokatalitik yang bergantung terhadap waktu. Kemungkinan besar dipengaruhi oleh karakteristik permukaan dan situs aktif yang ada pada material fotokatalis. Kemampuan degradasi yang terbaik diperankan oleh $\mathrm{ZnO}$ :Al/GO yang memiliki aspek rasio tertinggi, yaitu memiliki perbandingan antara panjang dan diamater batang yang besar. Lapisan $\mathrm{ZnO}: \mathrm{Al} / \mathrm{GO}$ memiliki kemampuan mendegradasi $\mathrm{MB}$ sebanyak 1,9 mikrogram/mg dalam waktu 300 menit.

\section{Kesimpulan}

Lapisan $\mathrm{ZnO}: \mathrm{Al}, \mathrm{ZnO}: \mathrm{Al} / \mathrm{GO}$ dan $\mathrm{ZnO}: \mathrm{GO}$ telah berhasil disintesis dengan menggunakan metode sol-gel degan teknik dip-coating untuk pelapisan seed layer dan self assembly untuk penumbuhan lapisan submicron-rods. Hasil karakterisasi SEM menunjukkan submicron-rods yang terbentuk pada lapisan $\mathrm{ZnO}$ memiliki bentuk rods yang homogen, cukup teratur dan cukup rapat. Lapisan $\mathrm{ZnO}$ :Al dan $\mathrm{ZnO}: \mathrm{Al} / \mathrm{GO}$ memiliki bentuk rods yang non-homogen, tidak beraturan dan cukup rapat. Sedangkan, lapisan $\mathrm{ZnO}: \mathrm{GO}$ menunjukkan rods yang non-homogen, cukup teratur tetapi kurang rapat. Hasil karakterisasi XRD menunjukkan bahwa lapisan $\mathrm{ZnO}, \mathrm{ZnO}: \mathrm{Al}, \mathrm{ZnO}: \mathrm{Al} / \mathrm{GO}$ dan $\mathrm{ZnO}$ GO memiliki struktur kristal hexagonal wurtzite dengan arah kristal dominan terhadap sumbu-c. Penambahan dopan Al mampu mereduksi ukuran partikel $\mathrm{ZnO}$ dan menyebabkan adanya self-attraction. Penambahan dopan GO terhadap $\mathrm{ZnO}$ submicron-rods menyebabkan bentuk rods menjadi tidak homogen dan terjadi peningkatan diameter rods. Nilai efisiensi degradasi tidak dapat dibandingkan karena berkaitan dengan perbandingan antara 
MB dengan serbuk material katalis yang berbeda. Selain itu, Koefisien laju degradasi berkaitan dengan kecepatan reaksi/aktivitas fotokatalitik yang bergantung terhadap waktu. Pada dasarnya, aktivitas fotokatalitik kemungkinan besar dipengaruhi oleh karakteristik permukaan dan situs aktif yang ada pada material fotokatalis. Kemampuan degradasi yang terbaik diperankan oleh $\mathrm{ZnO}: \mathrm{Al} / \mathrm{GO}$ yang memiliki aspek rasio tertinggi, yaitu memiliki perbandingan antara panjang dan diamater batang yang besar. Lapisan $\mathrm{ZnO}: \mathrm{Al} / \mathrm{GO}$ memiliki kemampuan mendegradasi MB sebanyak 1,9 mikrogram/mg dalam waktu 300 menit.

\section{Daftar Pustaka}

1. T.N. Sucahya, N. Permatasari, A.B.D. Nandiyanto. Review: Fotokatalis untuk Pengolahan Limbah Cair. Jurnal Integrasi Proses Vol. 6 (2016), No. 1.1 - 15.

2. Suyasa, W. Budiarsa. Pencemaran Air dan Pengolahan Air Limbah. Udayana University Press (2015).

3. C. Kencanawati, Sistem Pengelolaan Air Limbah. Universitas Udayana (2016).

4. Yuda, Hanum, H. Susanto. Analisis Sifat Optik Lapisan Tipis Bilayer $\mathrm{ZnO} / \mathrm{TiO} 2$ yang Dideposisikan Menggunakan Metode Sol-Gel Spray Coating dan Aplikasinya Sebagai Fotodegradasi Zat Warna. Youngster Physics Journal ISSN : 2303 - 7371. Vol. 3, No. 3, Juli (2014), Hal 223-230.

5. R.E. Kirk and V.R. Othmer Encyclopedia of Chemical Technology, vol.11 Flavor Characterization to Fuel Cells, 4th ed., John Wiley \& Sons Inc., New York (1994).

6. J. Yang and S. Gunasekaran. Electrochemically reduced graphene oxide sheets for use in hightt performance supercapacitors. Carbon N. Y., (2013) 51, 36-44.

7. S. Mondal, S. R. Bhattacharyya, P. Mitra. Effect of Al doping on microstructure and optical band gap of $\mathrm{ZnO}$ thin film synthesized by successive ion layer adsorption and reaction. Pramana, 80, 2 (2013), 315-326.

8. Wulandari, I. Oktavia. S. Wardhani, Danar Purwonugroho. Sintesis dan Karakterisasi Fotokatalis ZnO Pada Zeolit. Kimia.Student Journal, Vol. 1, No. 2 (2014), Pp. 241-247, Universitas Brawijaya Malang.

9. R. Hutabarat, Sintesis dan Karakteristik Fotokatalis Fe2+-ZnO Berbasis Zeolit Alam. Skripsi. Fakultas Teknik Universitas Indonesia. Depok (2012).

10. A. Aprilia, H. Fernando, L. Safriani, A. Bahtiar, R. Hidayat. Pengaruh Dopan Al Terhadap Struktur dan Morfologi ZnO Nano-rod dan Penggunaannya Sebagai Fotoanoda Pada Sel Surya DSSC. Prosiding SNIPS (2017).

11. Y. Shen, L. Lei, X. Zhang, M. Zhou, Y. Zhang. Effect of various gases and chemical catalysts on phenol degradation pathways by pulsed electrical discharges. Journal of Hazardous Materials, 150, 3 (2008), 713-722.

12. M.D. Stoller, S. Park, Y. Zhu, J. An, and R.S. Ruoff, Am. Graphene based ultracapacitors. Chem.Soc., 8(10) (2008)., 3498-3502.

13. S. Pei and H. Cheng. Synthesis of Graphene Oxide (GO) by Modified Hummers Method and Its Thermal Reduction to Obtain Reduced Graphene Oxide (rGO)*.Carbon N. Y., Vol. 11 (2011)., 1-19.

14. S. Park and R.S. Ruoff, Chemical methods for the production of ghraphene. Nat. Nanotechnology, 4 (2009), 217-224.

15. H. Choi, S. Jung, J. Seo, and D.Wook. Graphene for energy conversion and storage in fuel cells and supercapacitors. Nano Energy, 1(4) (2012). 534-551. 
16. Yu, Zhiqiang, S.C. Steven, Chuang. The effect of Pt on the photocatalytic degradation pathway of methylene blue over $\mathrm{TiO} 2$ under ambient conditions. Applied Catalysis B: Environmental 83 (2008), 277-285.

17. F. Ajala, A. Hamrouni, A. Houas, H. Lachheb, B. Megna, L. Palmisano, F. Parrino. The Influence of Al Doping on The Photocatalytic Activity of Nanostuctured ZnO: The Role of Adsorbed Water 445 (2018). 376-384.

18. J. Goldstein, D. Newbury, D. Joy, C. Lyman, P. Echlin, E. Lifshin et al.. Scanning electron microscopy and x-ray microanalysis. 3rd ed. New York: Springer (2003). 